\title{
Morphological Study of Cutaneous Ligaments of Phalanges
}

\author{
Estudio Morfológico de los Ligamentos Cutáneos de las Falanges
}

\begin{abstract}
Anjali Sabnis
SABNIS, A. Morphological study of cutaneous ligaments of phalanges. Int. J. Morphol., 31(2):606-608, 2013.

SUMMARY: The cutaneous ligaments of phalanges of palm and foot are fine and sender fibrous strips running from tendon sheath to flexor and extensor aspect of skin over phalanges. They are playing important role in stabilizing skin during movements and supporting digital neurovascular bundle. Such ligaments have carried lot of surgical value in microsurgery of hand. The morphology of such ligaments is studied in 80 digits of 8 cadavers of 20-80 years (6 males and 2 females). They are studied in detail in terms of attachments, thickness \& length. The morphological data will be helpful in surgical implication of Duputren's Contracture, replantation, revascularization of the digit.
\end{abstract}

KEY WORDS: Cutaneous ligaments; Cleland's ligament; Grayson's ligaments; Duputren's contracture.

\section{INTRODUCTION}

The anatomy and function of fingers has created interest amongst anatomist and surgeons since long time. To understand normal function of finger and identify the cause of disease, anatomy of fingers forms a strong foundation. The cutaneous ligaments of the fingers are fine, small but important structures, running from synovial sheath to skin. These are present dorsal (Grayson's ligaments) and ventral (Cleland's Ligaments) to the digital nerves. These are first described as ligaments seen dorsal to digital nerves by Cleland (1878). Then Grayson mentioned that in addition to these ligaments there is also fibrous septum volar to digital nerves (Grayson, 1941). As these ligaments are attached to skin, they hold the skin in place during the movements of fingers \& also support the neurovascular bundle. They also prevent the skin bagging to the sides of joints in flexion (Cleland).

The Cleland's ligaments divide the subcutaneous space into palmer and dorsal compartments of the fingers. This is clinically significant with respect to spread of inflammation and tumour (Schmidt \& Lanz, 2004). These ligaments are surgically important. We aimed to do morphological study of these ligaments. The detail knowledge regarding these ligaments will be useful for surgeons during the surgical implication of Duputren's contracture, replantation and revascularization of the digit.

\section{MATERIAL AND METHOD}

Eighty fingers and 80 toes of 6 males and 2 females embalmed cadavers ranging from 20 to 80 years, from department of Anatomy of K. J. Somaiya Medical College were dissected by taking midline incision on palmer and dorsal aspect of finger and toe. The skin was separated from underlying tissue. The synovial sheath of the tendon was identified and the ligaments running from it to the skin were observed and studied in relation to digital nerves. Their extent, thickness structure was studied by taking measurements.

\section{RESULTS}

Palmer cutaneous ligaments are seen running from synovial sheath of tendon to the skin while dorsal cutaneous ligaments are running from either side of phalanges to the skin (Fig. 1).

Dorsal ligaments are thicker, broader\& obliquely arranged. Palmer ligaments are thinner, straight. Palmer ligaments are prominently seen at proximal interphalangeal joint and on proximal phalanx. Cutaneous ligaments of toes are prominently seen on dorsal aspect. 


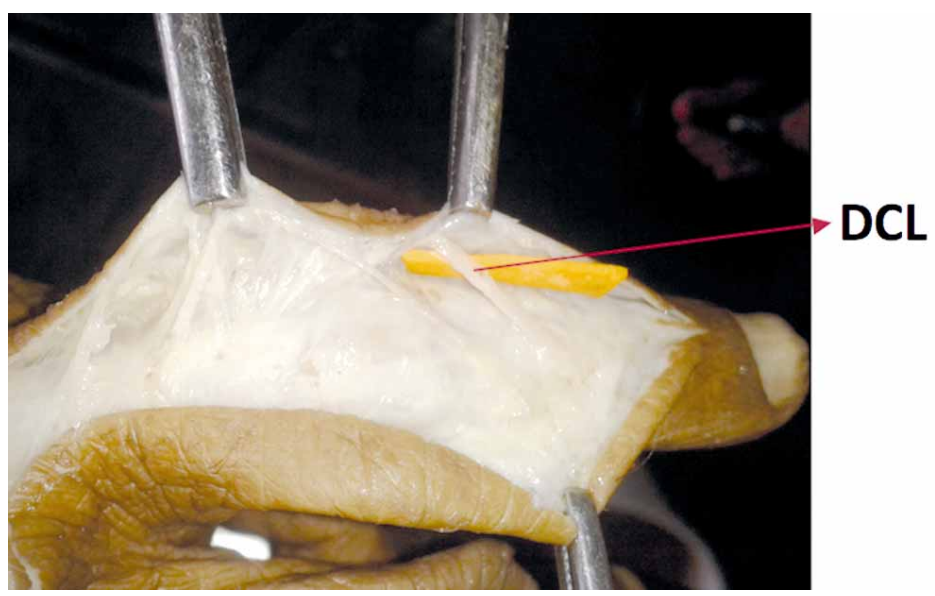

Fig. 1. Shows Dorsal cutaneous ligament (DCL).

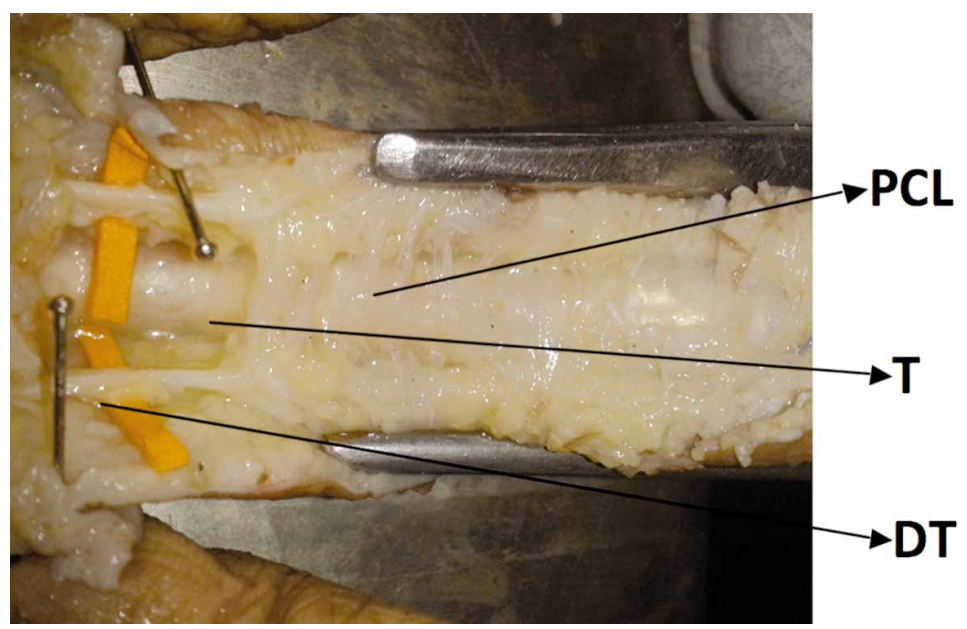

Fig. 2: Shows palmer cutaneous ligaments (PCL), tendon (T) and digital nerve (DN).

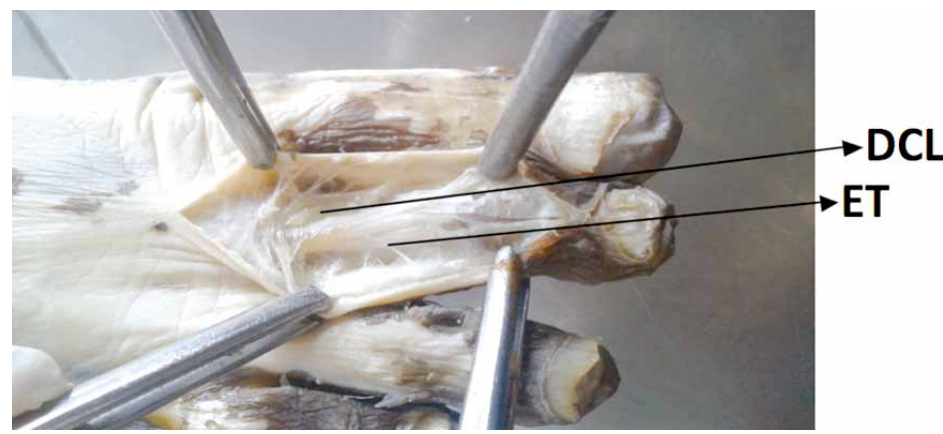

Fig. 3. Shows cutaneous ligaments on dorsal aspect of 2 nd toe (DCL) and extensor tendon (ET).

Table I. Mean length of cutaneous ligaments of palm.

\begin{tabular}{lcc}
\hline & Cleland's Ligaments & Grayson's \\
\cline { 2 - 3 } Location & Mean length & Mean length \\
\hline Thumb & $4 \mathrm{~cm}$ & $3 \mathrm{~cm}$ \\
Index finger & $5 \mathrm{~cm}$ & $3.2 \mathrm{~cm}$ \\
Middle finger & $5 \mathrm{~cm}$ & $4 \mathrm{~cm}$ \\
Ring finger & $4 \mathrm{~cm}$ & $3 \mathrm{~cm}$ \\
Little finger & $4 \mathrm{~cm}$ & $2.8 \mathrm{~cm}$ \\
\hline
\end{tabular}

\section{DISCUSSION}

Presence of cutaneous ligaments was first mentioned by Weitbrechtin (1742). Then Cleland described dorsal cutaneous ligaments as fibrous septum dorsal to digital nerves. Grayson opined that in addition to these structures there is also a fibrous septum volar to the digital nerves. This septum forms a series of retinacula which might be termed as superficial or volar retinacula (Grayson). Milford disagrees with the septal concept of these ligaments and described these fibers are forming a cone like structure before inserting into skin (Milford, 1968). We found that dorsal cutaneous ligaments are running obliquely from phalanges to the skin. They are much thicker, denser than palmer cutaneous ligaments. Some ligaments are of $\mathrm{v}$ shaped (Sindel et al., 2011) and we are agreed to it (Fig. 2). They are seen on the dorsal side all over the phalanx. While palmer cutaneous ligaments are thinner and running straight from tendon to the skin. They are prominently seen on proximal phalanx and proximal interphalangeal joint. These fibres are most prominent in the middle section of proximal phalanx and over the entire length of middle phalanx as far as the distal interphalageal joint (Grayson). They are either perpendicular to the skin or oblique and forms interlaced network of fibers superficial to the flexor tendon sheath (Knott \& Schmidt, 1986). The distance between the attachments is measured (Table I). The mean thickness of the ligaments is $1.2 \mathrm{~mm}$ on dorsal aspect and $0.8 \mathrm{~mm}$ on palmer aspect. Such cutaneous ligaments are seen in foot also. They are much prominent on dorsal aspect than plantar aspect (Fig. 3).

Dupuytren's contracture or palmar fibromatosis is an inherited proliferative connective tissue disorder which involves the palmar fascia of the hand. It may involve cutaneous ligaments to varying degrees (McFarlane, 1974; Barton, 1984). Cleland's ligaments are never diseased in Duputren's contracture but Grayson's ligaments which are thinner and delicate than Cleland's ligaments often diseased in Duputren's contracture. Also in cutaneous syndactyly, the Cleland's ligaments of adjacent fingers interlace and form perpendicular septa in the area of adhesion (Schmidt \& Lanz). Both the ligaments carry a lot of surgical importance. Digital fascia has got 
SABNIS, A. Morphological study of cutaneous ligaments of phalanges. Int. J. Morphol., 31(2):606-608, 2013.

connection with the superficial transverse ligament, Grayson's ligament and digital bands.

In the foot the cutaneous ligaments are seen more prominent on extensor aspect running from extensor tendons to the skin. They are more prominent proximally but thinner and shorter as compared to hand ligaments. They are less distinctly seen at the distal joint of the toes (Cleland). The mean thickness of ligaments is $0.5 \mathrm{~mm}$ and length is $6 \mathrm{~mm}$ on dorsal aspect.

The Morphological data related to these ligaments will be helpful for the surgeons during microsurgery of the hand and foot.

SABNIS, A. Estudio morfológico de los ligamentos cutáneos de las falanges. Int. J. Morphol., 31(2):606-608, 2013.

RESUMEN: Los ligamentos cutáneos de las falanges de los dedos de la mano y del pie son delgadas cintas fibrosas que recorren bajo la piel y sobre las falanges la vaina de los tendones de los músculos flexor y extensor de los dedos. Tienen un rol importante en la estabilización de la piel durante los movimientos y mantienen el paquete neurovascular digital. Estos ligamentos tienen un gran valor quirúrgico en procedimientos como la microcirugía de mano. Se estudió la morfología de estos ligamentos en 80 dedos de 8 cadáveres de individuos entre 20 y 80 años de edad (6 hombres y 2 mujeres). Fue estudiada en detalle la anatomía en términos de uniones, espesor y longitud de estos ligamentos. Los datos morfológicos serán de utilidad en procedimientos quirúrgicos como el Síndrome de Duputren, reimplantación y revascularización de los dedos.

PALABRAS CLAVE: Ligamentos cutáneos; Ligamento de Cleland; Ligamento de Grayson; Contractura de Duputren.

\section{REFERENCES}

Barton, N. J. Dupuytren's disease arising from the abductor digiti minimi. J. Hand Surg. Br., 9(3):265-70, 1984.

Cleland, J. On the Cutaneous Ligaments of the Phalanges. J. Anat. Phys., 12:526, 1878.

Grayson, J. The cutaneous ligaments of the digits. J. Anat., 75(Pt 2):164-5, 1941.

Knott, C. \& Schmidt, H. M. Die bindegewebigen Verstärkungseinrichtungen der digitalen Sehnenscheiden an der menschlichen Hand. Gegenbaurs Morphol. Jahrb, 132(1):128, 1986.

McFarlane, R. M. Patterns of the diseased fascia in the fingers in Dupuytren's contracture. Displacement of the neurovascular bundle. Plast. Reconstr. Surg., 54(1):31-44, 1974.

Milford, L. W. Retaining Ligaments of the digits of the hand: Gross and microscopic study. Philadelphia, W. B. Saunders, 1968. pp.598-9.

Schmidt, H. M. \& Lanz, U. Surgical anatomy of Hand. Cutaneous ligaments. Stuttgart, Thieme, 2004.

Sindel, M.; Arican, R. Y.; Ozcanli, H.; Cengiz, M.; Gur, S. \& Keles, N. Cleland's and Grayson's ligaments: an anatomic study. Fizyoterapi Rehabilitasyon, 22(3):245-8, 2011.

Weitbrecht, J. Syndesmologia sive historia ligamentorum corporis human. St. Petersburg, Petropol, 1742.

\author{
Correspondence to: \\ Dr. Anjali Sabnis \\ K. J. Somaiya Medical College and Hospital \\ Sion, Mumbai \\ 43/B, Kamgar nagar \\ Kurla (E), 24, Mumbai \\ INDIA
}

Phone: 9820493036

Fax: 02224091855

Email dranjus2003@yahoo.com

Received: 29-09-2012

Accepted: 17-11-2012 